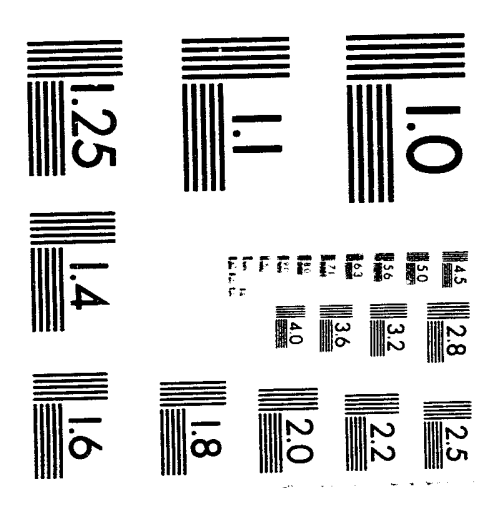



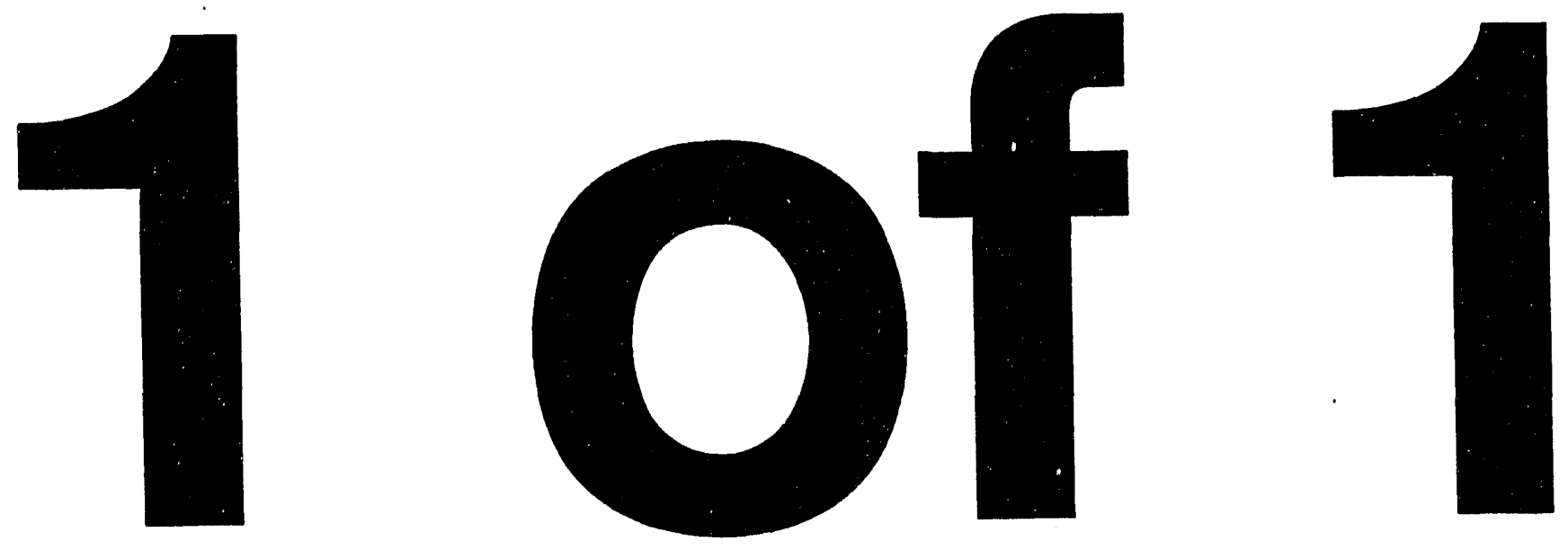
This report was prepared as an account of work sponsored by an agency of the United States Government. Neither the United States Government nor any agency thureof, nor any of their employees, makes any warranty, express or implied, or assumes any legal liability or responsibility for the accuracy, completeness, or usefulness of any information, apparatus, product, or process disclosed, or represents that its use would not infringe privately owned rights. Reference herein to any specific commercial product, process, or service by trade name, trademark, manufacturer, or otherwise does not necessarily constitute or imply its endorsement, recommendation, or favoring by the United States Government or any agency thereof. The views and opinions of authors expressed herein do not necessarily state or reflect those of the United States Government or any agency thereof.

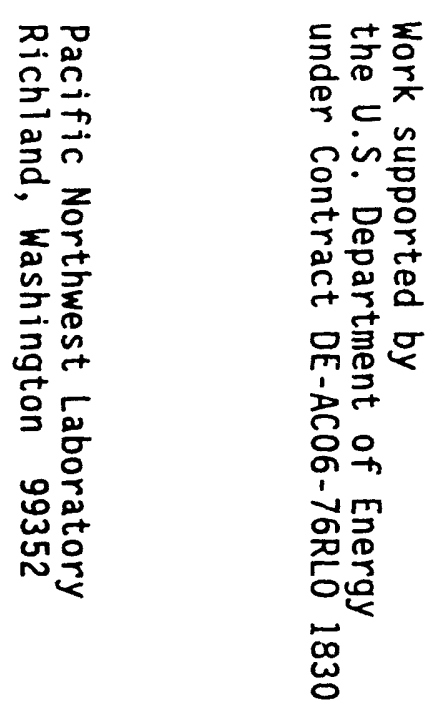
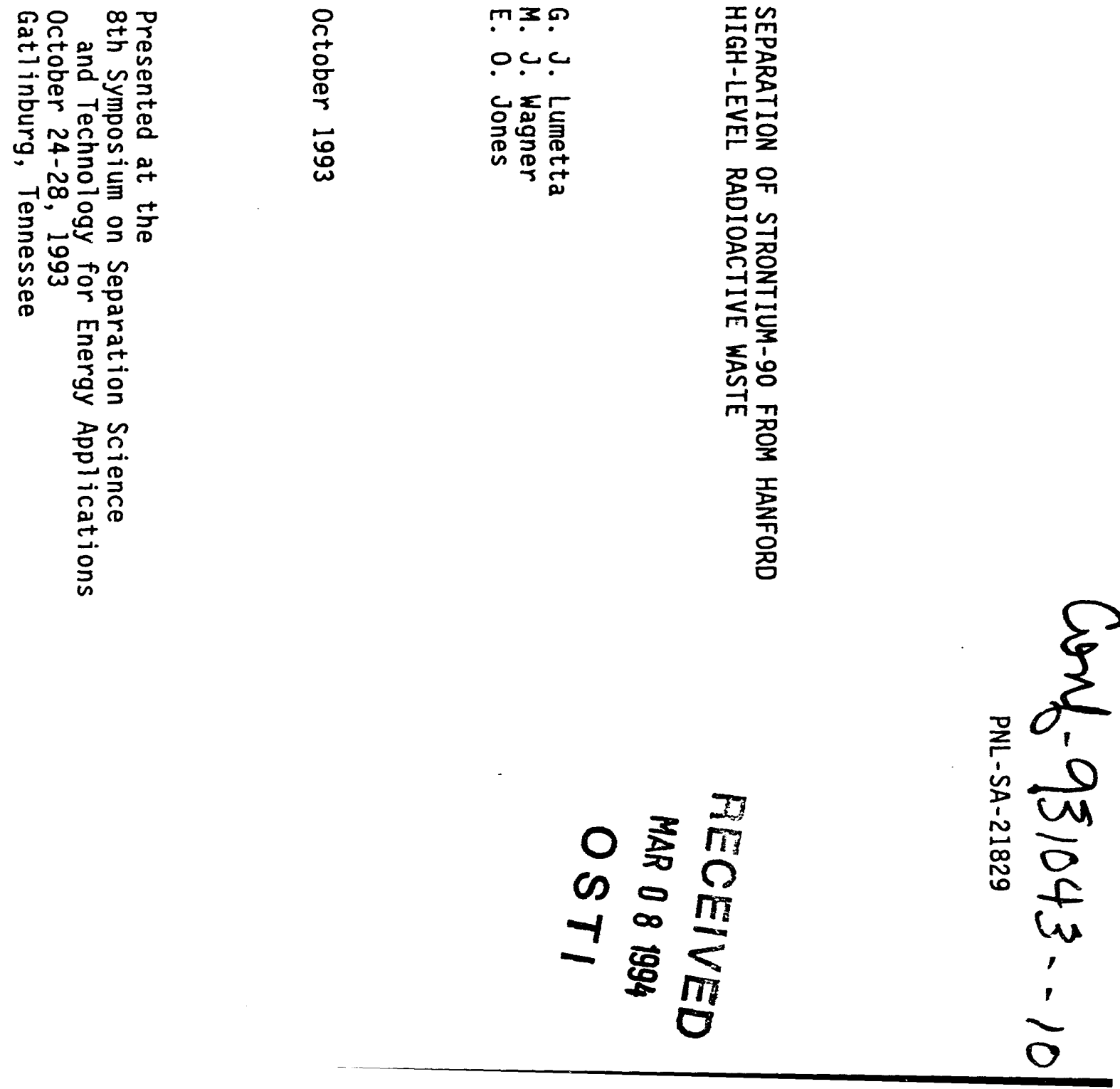


\title{
SEPARATION OF STRONTIUM-90 FROM HANFORD HIGH-LEVEL RADIOACTIVE WASTE
}

\author{
Gregg J. Lumetta, (a) Michael J. Wagner, \\ and Evan 0. Jones
}

Chemical Technology Department

Pacific Northwest Laboratory (b)

P.0. Box 999, P7-25

Richland, Washington, 99352

\begin{abstract}
Current guidelines for disposing of high-level radioactive wastes stored in underground tanks at the U.S. Department of Energy's Hanford Site call for vitrifying high-level waste (HLW) in borosilicate glass and disposing the glass canisters in a deep geologic repository. Disposition of the low-level waste (LLW) is yet to be determined, but it will likely be immobilized in a glass matrix and disposed of on site. To lower the radiological risk associated with the LLW form, methods are being developed to separate ${ }^{90} \mathrm{Sr}$ from the bulk waste material so this isotope can be routed to the HLW stream. A solvent extraction method is being investigated to separate ${ }^{90} \mathrm{Sr}$ from acid-dissolved Hanford tank wastes. Results of experiments with actual tank waste indicate that this method can be used to achieve separation of ${ }^{90} \mathrm{Sr}$ from the bulk waste components. Greater than 998 of the ${ }^{90} \mathrm{Sr}$ was removed from an acidic dissolved sludge solution by extraction with di-tbutylcyclohexano-18-crown-6 in 1-octanol (the SREX process). The major sludge components were not extracted.
\end{abstract}

(a) Author to whom correspondence should be addressed.

(b) Pacific Northwest Laboratory is operated for the U.S. Department of Energy b; Battelle Memorial Institute under Contract DE-ACU6-76F.LO 1830. 


\section{INTRODUCTION}

Methods are being developed to treat and dispose of large volumes of radioactive wastes stored in underground tanks at the U.S. Department of Energy's (DOE) Hanford Site. The current baseline scenario for treating and disposing of these wastes would partition the wastes into high-level waste (HLW) and low-level waste (LIW) streams. The HLW will be vitrified into borosilicate glass and disposed of in a geologic repository while the LLW will be immobilized in a glass matrix and will likely be disposed of by shallow burial at the Hanford Site.

Separating various radionuclides from the bulk waste components is desirable for both economic and environmental reasons. Because vitrifying and disposing of $\mathrm{HLW}$ is expected to be considerably more costly than disposing of LLW, it would be beneficial to minimize the volume of HLW by segregating the radionuclides into a concentrated waste stream. Furthermore, maximum removal of radionuclides from the LLW stream would lower the risk of radioactive material leaching from the LLW matrix into the surrounding environment.

The Hanford tank wastes are highly alkaline $(\mathrm{pH}>13)$, and consist of three general physical forms: 1) supernatant liquid, 2) salt cake, (c) and 3) sludge. Except for ${ }^{137} \mathrm{Cs}$ and ${ }^{99} \mathrm{Tc}$, the majority of the radionuclides are in the tank sludges. Thus, separation techniques for radioisotopes other than ${ }^{137} \mathrm{Cs}$ and ${ }^{99} \mathrm{Tc}$ are generally directed at treating the tank sludge materials.'

The transuranic extraction (TRUEX) process for separating the transuranic elements (primarily Am and $\mathrm{Pu}$ ) from acid-dissolved Hanford tank sludges has been investigated for a number of years (19). More recently, di-t-butyl-cyclohexano-18-crown-6 (DtBC18C6) has been investigated for extracting ${ }^{90} \mathrm{Sr}$ from acid-dissolved Hanford tank sludges. The process in which $\mathrm{Sr}$ is extracted with DtBC18C6

(c) The salt cake, consisting primarily of sodium salts (nitrate, nitrite, aluminate, and hydroxide), was formed by evaporation of tank supernatant liquids. 
was developed by workers at Argonne National Laboratory, and it has been termed the SREX process (10).

This paper describes the results of experiments conducted to test the SREX process for separating ${ }^{90} \mathrm{Sr}$ from the bulk constituents of Hanford tank sludge. Portions of an actual Hanford tank sludge were used in these experiments. The sludge used was taken from tank number B-110, and it contained $-220 \mu \mathrm{Ci}\left(8.1 \times 10^{6} \mathrm{~Bq}\right){ }^{90} \mathrm{Sr}$ per gram of sludge.

\section{EXPERIMENTAL}

The SREX process was examined in two different tests. The batch solvent extraction contacts performed in these tests are summarized in Figures 1 and 2 and in Tables 1 and 2 . Composite core samples from two different locations within the tank were used for these tests.

\section{Procedure for the First SREX Test}

For the first test, a $5.24-\mathrm{g}$ portion of sludge from Tank B-110 was washed twice with 10-mL portions of $0.1 \mathrm{M} \mathrm{NaOH}$ at room temperature. These washes were performed by mixing the sludge with the $0.1 \mathrm{M} \mathrm{NaOH}$ for 1 to $2 \mathrm{~h}$, centrifuging, and then decanting the wash liquor from the sludge.

To dissolve the washed sludge, water was added to give a total volume of $10 \mathrm{~mL}$; then $\mathrm{HNO}_{3}(2.9 \mathrm{~mL}$ of $15.7 \mathrm{M})$ and $\mathrm{HF}(0.15 \mathrm{~mL}$ of 10 M) were added along with enough water to give a total volume of 15 $\mathrm{mL}$. After stirring at $100^{\circ} \mathrm{C}$ for $1 \mathrm{~h}$, another $0.15 \mathrm{~mL}$ of $10 \mathrm{M} \mathrm{HF}$ was added. The dissolver mixture was heated for another $2 \mathrm{~h}$, then was allowed to cool. After centrifuging, the solution (Solution 1 ) was decanted. Water ( $5 \mathrm{~mL}$ ) and $10 \underline{\mathrm{M}} \mathrm{HF}$ ( $1 \mathrm{~mL}$ ) were added to the undissolved solid. The mixture was stirred at room temperature overnight, which resulted in most of the solid being dissolved. More was dissolved by heating the mixture for $1 \mathrm{~h}$ at $100^{\circ} \mathrm{C}$. The solution (Solution 2) was cooled and centrifuged, then was decanted from the small amount of residual solid. Solutions 1 and 2 were 
filtered through $0.2-\mu \mathrm{m}$ filters.

The feed solution (Solution 3) was prepared by mixing $2.5 \mathrm{~mL}$ of Solution 1, $2.5 \mathrm{~mL}$ of Solution 2, $1 \mathrm{~mL}$ of $15.7 \mathrm{M} \mathrm{HNO}_{3}$, and $4 \mathrm{~mL}$ of water. The composition of solution 3 is given in Figure 1 . This solution was contacted with $3 \mathrm{~mL}$ of $0.2 \mathrm{M} \mathrm{DtBC18C6}$ in 1-octanol (the SREX process solvent); then portions of each phase were taken for subsequent contacts, as outlined in Table 1 . In general, the contacts were performed by mixing the two phases for 30 to $60 \mathrm{sec}$. The mixtures were centrifuged before sampling to ensure complete phase separation.

The aqueous phases from each contact was sampled. The concentration of the bulk sludge components was determined by inductively coupled plasma/atomic emission spectroscopy (ICP). Acid concentrations were determined by potentiometric titration with standard $\mathrm{NaOH}$. Fluoride concentrations were determined potentiometrically using a fluoride-selective electrode. Strontium-90 concentrations for Solution 3 and each aqueous phase were determined by radiochemical analyses.

\section{Procedure for the Second SREX Test}

For the second test, a 3.43-g portion of Tank B-110 sludge was used. This sample was taken at a different position in the tank than the sample used in the first test. The sludge was slurried in $\sim 15 \mathrm{~mL}$ of $0.1 \mathrm{M} \mathrm{NaOH}$ and heated at $100^{\circ} \mathrm{C}$ for $1 \mathrm{~h}$. After cooling to room temperature, the mixture was centrifuged, and the clear supernatant solution was decanted. The sludge was washed in a similar manner with another $10-\mathrm{mL}$ portion of $0.1 \mathrm{M} \mathrm{NaOH}$, then was dissolved in acid as follows.

The washed sludge was mixed with $10 \mathrm{~mL}$ of water, giving a slurry with $\mathrm{pH}=11.9$. Nitric acid $(0.27 \mathrm{~mL}$ of $15.7 \mathrm{M})$ was added to lower the $\mathrm{pH}$ to 1.0. An additional $1.8 \mathrm{~mL}$ of $15.7 \mathrm{M} \mathrm{HNO}$ was added to yield an effective $\mathrm{HNO}_{3}$ concentration of approximately $2 \underline{\mathrm{M}}$. The dissolution mixture was heated at $100^{\circ} \mathrm{C}$ for $1 \mathrm{~h}$, then was allowed to cool to ambient temperature. Nearly all of the solids dissolved. 
The dissolution mixture was centrifuged, and the dissolved sludge solution (Solution 4) was decanted from the small amount of residual solids. The residual solids were treated with $5.3 \mathrm{~mL}$ of $1.9 \mathrm{M} \mathrm{HNO}_{3} / 0.6 \mathrm{M} \mathrm{HF}$ at $100^{\circ} \mathrm{C}$ for $1 \mathrm{~h}$ resulting in complete dissolution of the remaining solids (Solution 5 ). The two dissolved sludge solutions ( 4 and 5 ) were combined for use in the solvent extraction test (Solution 6 ).

Before conducting the second SREX test, Solution 6 was used in a test of the TRUEX process $(1,2)$ for separating the transuranic elements from the dissolved sludge solution. Solution 6 (13.8 $\mathrm{mL}$ ) was mixed with $2.2 \mathrm{~mL}$ of $2.0 \mathrm{M} \mathrm{HNO}_{3}$ and $4.4 \mathrm{~mL}$ of a solution that was $0.01 \mathrm{M} \mathrm{HNO}_{3}$ and $0.01 \underline{\mathrm{M}}$ ascorbic acid to give solution 7 . The latter two solutions were added to represent the blending of the TRUEX scrub solutions with the feed solution that would occur in the TRUEX extraction stages. Solution 7 was contacted two successive times with the TRUEX process solvent(d) at an organic-to-aqueous phase ratio equal to 0.5 . (e)

Fourteen milliliters of the aqueous phase from the second TRUEX extraction were mixed with 1 ) $3.3 \mathrm{~mL}$ of $15.7 \mathrm{M} \mathrm{HNO}_{3}$ (to increase the $\mathrm{HNO}_{3}$ concentration, and thus, increase the $\mathrm{Sr}$ distribution coefficient), 2) $2.6 \mathrm{~mL}$ of $1.0 \mathrm{M} \mathrm{HNO}_{3}$ (to represent blending with the scrub stream), and 3) ${ }^{85} \mathrm{Sr}$ tracer solution (so that the behavior of $\mathrm{Sr}$ could be followed by gamma counting techniques). The resulting solution (Solution 8 ) was subjected to a series of extraction, scrub, and strip steps as outlined in Figure 2 and Table 2.

(d) The TRUEX process solvent consisted of $0.2 \mathrm{M}$ octyl(phenyl)$\mathrm{N}, \mathrm{N}$-diisobutylcarbamoylmethylphosphine oxide plus $1.4 \mathrm{M}$ tributyl phosphate in a normal paraffin hydrocarbon.

(e) Because the focus of this paper is on Sr separation, the results of the TRUEX test will not be reported here. 


\section{RESUITS AND DISCUSSION}

\section{First SREX Test}

In the first SREX test, a dissolved B-110 sludge solution was contacted three successive times with the SREX process solvent at an organic-to-aqueous phase ratio equal to 0.33 . The results are shown in Figure 3. Greater than 998 of the $\mathrm{Sr}$ was extracted from the aqueous feed solution; the decontamination factor(f) for ${ }^{90} \mathrm{Sr}$ was 250. Of the major sludge components present, only Na extracted to any extent, and this did not occur until the third extraction contact. Because the scrub steps were only tested on the organic phase from the first extraction contact, the behavior of $\mathrm{Na}$ in the scrubbing stages could not be determined. But based on published distribution coefficients (10), Na should have been readily scrubbed from the extract. The amount of $\mathrm{H}^{+}$extracted was consistent with published data on the SREX process (10). Barium and $\mathrm{Pb}$, which are minor constituents of the waste, were extracted along with the $\mathrm{Sr}$.

The organic phase from the first extraction was subjected to a series of scrub and strip contacts as outlined in Table 1 . The concentration profile for ${ }^{90} \mathrm{Sr}$ for all the contacts is given in Figure 4. The behavior of ${ }^{90} \mathrm{Sr}$ can be summarized as follows:

- Greater than 998 of the ${ }^{90} \mathrm{Sr}$ was extracted from the aciddissolved sludge solution.

- Eighty-eight percent of the extracted ${ }^{90} \mathrm{Sr}$ remained in the organic phase after the second scrub contact.

- Strontium-90 was stripped easily with $0.01 \mathrm{M} \mathrm{HNO}_{3}$.

This initial SREX test served as a proof-of-principle that the SREX process can be used to separate ${ }^{90} \mathrm{Sr}$ from dissolved Hanford tank sludges. Significant loss of ${ }^{90} \mathrm{Sr}$ from the extract during the scrub

(f) The decontamination factor (DF) is defined as the quantity of a certain component initially present in the waste divided by the quanitity of that component present after treatment. 
steps indicated that a different scrub solution might be needed to improve the process performance. Another test was conducted (Figure 2, Table 2) using $1.0 \mathrm{M} \mathrm{HNO}_{3}$ as the scrub solution.

\section{Second SREX Test}

In the second SREX test, a dissolved B-110 sludge solution was contacted four successive times with the SREX process solvent at an organic-to-aqueous phase ratio equal to 0.33 . The organic phase from the first extraction was subjected to a series of scrub and strip steps. The $S x$ concentration profile is given in Figure 5 . The process performed as expected. Strontium was extracted efficiently ( $D F-9,000$ ), retained in the extract during the scrubbing contacts, and stripped with $0.01 \mathrm{M} \mathrm{HNO}_{3}$. The distribution coefficient for $\mathrm{Sr}$ in the first strip contact was 0.8 , which is somewhat high for efficient stripping. Under continuous counter-current conditions, a flowsheet employing a $0.5 \mathrm{M} \mathrm{HNO}_{3}$ scrub solution may be more desirable. As was indicated in the first test (Figure 4), the $\mathrm{Sr}$ distribution coefficients remained well above one when $0.5 \mathrm{M} \mathrm{HNO}$ was used as the scrub solution, and stripping was much more efficient (the $\mathrm{Sr}$ distribution coefficient was 0.2 in the first strip contact of the first SREX test).

The Sr distribution coefficients measured during this experiment are compared to those reported in the literature (11) in Figure 6. The results obtained here agree very well with the literature values.

Lead was extracted along with $\mathrm{Sr}$; however, the extracted $\mathrm{Pb}$ was not stripped from the solvent. The $\mathrm{Pb}$ distribution coefficient in the first strip contact was $>11$. This implies that $\mathrm{Pb}$ can be separated from the $\mathrm{Sr}$, but a second strip section must be added to the process flowsheet to strip $\mathrm{Pb}$ from the solvent. 


\section{Conclusion}

The results of SREX tests with actual B-110 sludge indicate that this process can be used to separate ${ }^{90} \mathrm{Sr}$ from the bulk nonradioactive components of Hanford tank sludges. Using the SREX process, in combination with the TRUEX process, could greatly reduce the volume of HLW glass produced in disposing of Hanford tank wastes.

\section{ACKNOWLEDGEMENTS}

This work was supported in part by the U.S. Department of Energy, through the Office of Technology Development (EM-50) and the Office of Waste Management and Environmental Remediation (EM-30). The authors would like to thank B. M. Rapko and W. C. Cosby for reviewing this document.

\section{REFERENCES}

1. E. P. Horwitz, D. G. Kalina, H. Diamond, G. F. Vandegrift, and W. W. Schulz, Solvent Extr. Ion Exch., 3, 75 (1985).

2. W. W. Schulz and E.P. Horwitz, Sep. Sci. Technol., 23, 1191 (1988).

3. S. A. Barker, J. I. Swanson, and G. J. Lumetta, Transuranium Extraction Processing of Unique Hanford Waste: Process Engineering Observations, Report WHC-SA-1270-S, Westinghouse Hanford Company, Richland, Washington, 1991.

4. J. L. Swanson, Initial Studies of Pretreatment Methods for Neutralized Cladding Removal Waste (NCRW) Sludge, Report PNL7716, Pacific Northwest Laboratory, Richland, Washington, 1991.

5. J. L. Swanson, Use of the TRUEX Process for the Pretreatment of Neutralized Cladding Removal Waste (NCRW) Sludge - Results of FY 1990 Studies, Report PNL-7780, Pacific Northwest Laboratory, Richland, Washington, 1991.

6. J. L. Swanson, Use of the TRUEX Process for the Pretreatment of Neutralized Cladding Removal Waste (NCRW) Sludge - Results of 
a Design Basis Experiment, Report PNL-7734, Pacific Northwest Laboratory, Richland, Washington, 1991.

7. G. J. Lumetta and J. L. Swanson, Pretreatment of Neutralized Cladding Removal Waste (NCRW) Sludge - Results of FY 1991 Studies, Report PNL-8536, Pacific Northwest Laboratory, Richland, Washington, 1993.

8. G. J. Lumetta and J. L. Swanson, Pretreatment of Neutralized Cladding Removal Waste (NCRW) Sludge: Status Report, Report PNL-8558, Pacific Northwest Laboratory, Richland, Washington, 1993.

9. G. J. Lumetta and J. L. Swanson, Pretreatment of Plutonium Finishing Plant (PFP) Sludge: Report for the Period October 1990 - March 1992, Report PNL-8601, Pacific Northwest Laboratory, Richland, Washington, 1993.

10. E. P. Horwitz, M. L. Dietz, and D. E. Fisher, Solvent Extr. Ion Exch., 9, 1 (1991).

11. M. L. Dietz and E. P. Horwitz, LC-GC, 11, 424 (1993). 


\section{FIGURE CAPTIONS}

FIGURE 1. Schematic of the First SREX Test with Tank B-110 Sludge

FIGURE 2. Schematic of the Second SREX Test with Tank B-110 Sludge

FIGURE 3. Extraction Results from the First SREX Test with Tank B-110 Sludge

FIGURE 4. Strontium Concentration Profile from the First SREX Test with Tank B-110 Sludge

FIGURE 5. Strontium Concentration Profile from the Second SREX Test with Tank B-110 Sludge

FIGURE 6. Comparison of Sr Distribution Coefficients Determined in SREX Tests with Actual Tank B-110 Sludge to Those Reported in the Literature 
TABLE 1. SOLVENT EXTRACTION CONTACTS PERFORMED

IN THE FIRST SREX TEST (REFER TO FIGURE 1)

\begin{tabular}{|c|c|c|c|c|}
\hline Step & Aqueous Phase & Aq. Vol., $\mathrm{mL}$ & Organic Phase & Org. Vol., mL \\
\hline EXTR-1 & Solution 3 & 9.00 & $0.2 \mathrm{M} \mathrm{DtBC18C6}$ & 3.00 \\
\hline SCRUB-1 & $0.5 \underline{\mathrm{M}} \mathrm{HNO}_{3}$ & 0.83 & From EXTR-1 & 2.50 \\
\hline SCRUB-2 & $0.5 \underline{\mathrm{M} \mathrm{HNO}_{3}}$ & 0.67 & From SCRUB-1 & 2.00 \\
\hline STRIP-1 & $0.01 \underline{\mathrm{M}} \mathrm{HNO}_{3}$ & 1.50 & From SCRUB-2 & 1.50 \\
\hline STRIP-2 & $0.01 \mathrm{M} \mathrm{HNO}_{3}$ & 1.00 & From STRIP-1 & 1.00 \\
\hline STRIP-3 & $0.01 \underline{\mathrm{MNNO}}$ & 0.50 & From STRIP-2 & 0.50 \\
\hline EXTR-2 & From EXTR-1 & 3.00 & $0.2 \underline{\mathrm{M}} \mathrm{DtBC} 18 \mathrm{C} 6$ & 1.00 \\
\hline EXTR-3 & From EXTR-2 & 1.50 & $0.2 \underline{\mathrm{M}} \mathrm{DtBC} 18 \mathrm{C} 6$ & 0.50 \\
\hline
\end{tabular}

TABLE 2. SOLVENT EXTRACTION CONTACTS PERFORMED

IN THE SECOND SREX TEST (REFER TO FIGURE 2)

\begin{tabular}{|c|c|c|c|c|}
\hline Step & Aqueous Phase & Aq. Vol., mL & Organic Phase & Org. Vol., mL \\
\hline EXTR-1 & Solution 8 & 19.80 & $0.2 \underline{\mathrm{M}} \mathrm{DtBC} 18 \mathrm{C} 6$ & 6.53 \\
\hline SCRUB-1 & $1.0 \underline{\mathrm{M}} \mathrm{HNO}_{3}$ & 2.17 & From EXTR-1 & 5.50 \\
\hline SCRUB-2 & $1.0 \underline{\mathrm{M} \mathrm{HNO}_{3}}$ & 1.77 & From SCRUB-1 & 4.50 \\
\hline STRIP-1 & $0.01 \underline{\mathrm{MNO}_{3}}$ & 3.50 & From SCRUB-2 & 3.50 \\
\hline STRIP-2 & $0.01 \underline{\mathrm{M}} \mathrm{HNO}_{3}$ & 2.50 & From STRIP-1 & 2.50 \\
\hline STRIP-3 & $0.01 \underline{\mathrm{M} \mathrm{HNO}}$ & 1.50 & From STRIP-2 & 1.50 \\
\hline EXTR-2 & From EXTR-1 & 5.00 & $0.2 \underline{\mathrm{M}} \mathrm{DtBC} 18 \mathrm{C} 6$ & 1.65 \\
\hline EXTR-3 & From EXTR-2 & 3.00 & $0.2 \underline{\mathrm{M}} \mathrm{DtBC} 18 \mathrm{C} 6$ & 1.00 \\
\hline EXTR-4 & From EXTR-3 & 1.50 & $0.2 \underline{\mathrm{M}} \mathrm{D} \cdot \mathrm{BC} 18 \mathrm{C} 6$ & 0.50 \\
\hline
\end{tabular}




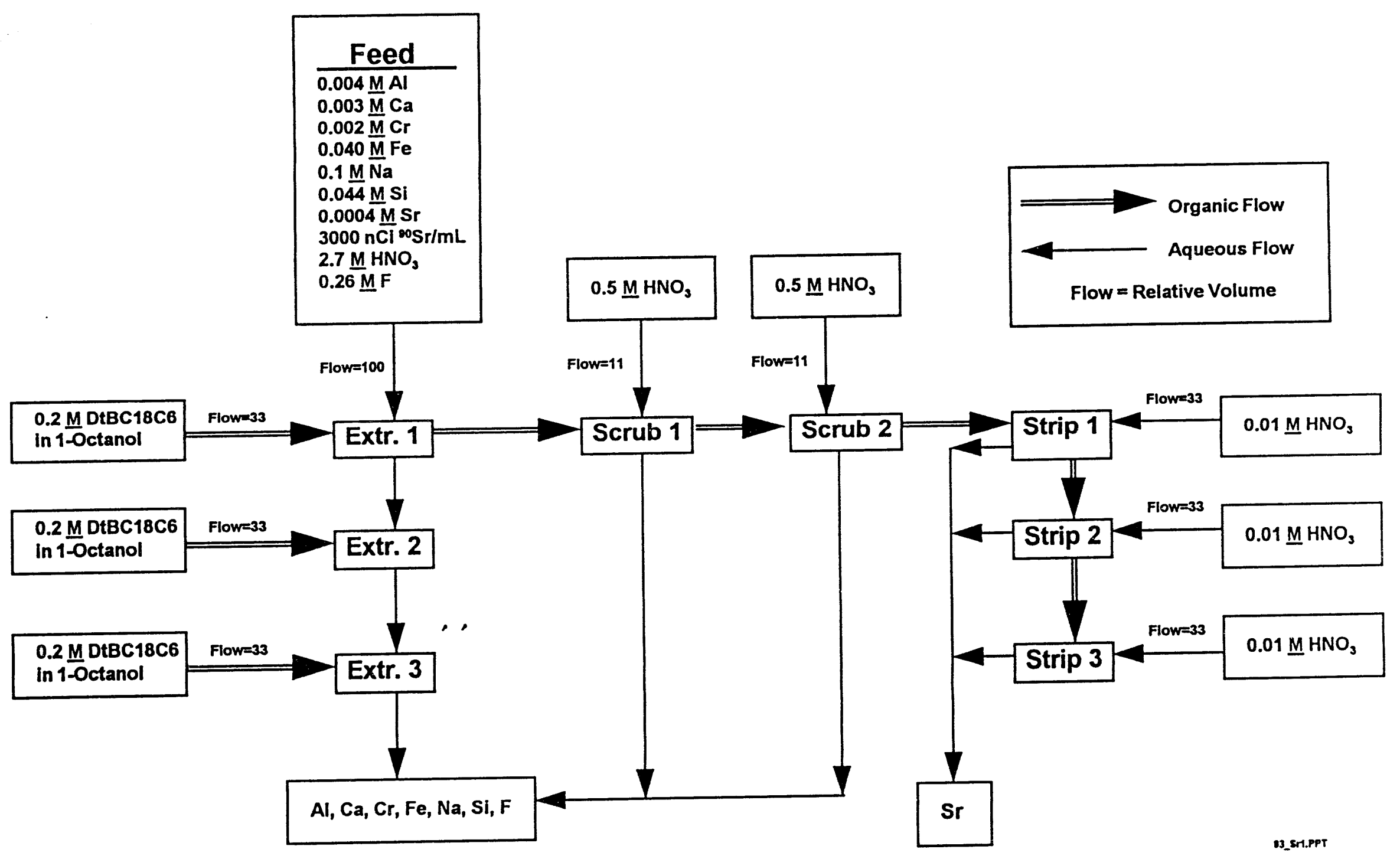




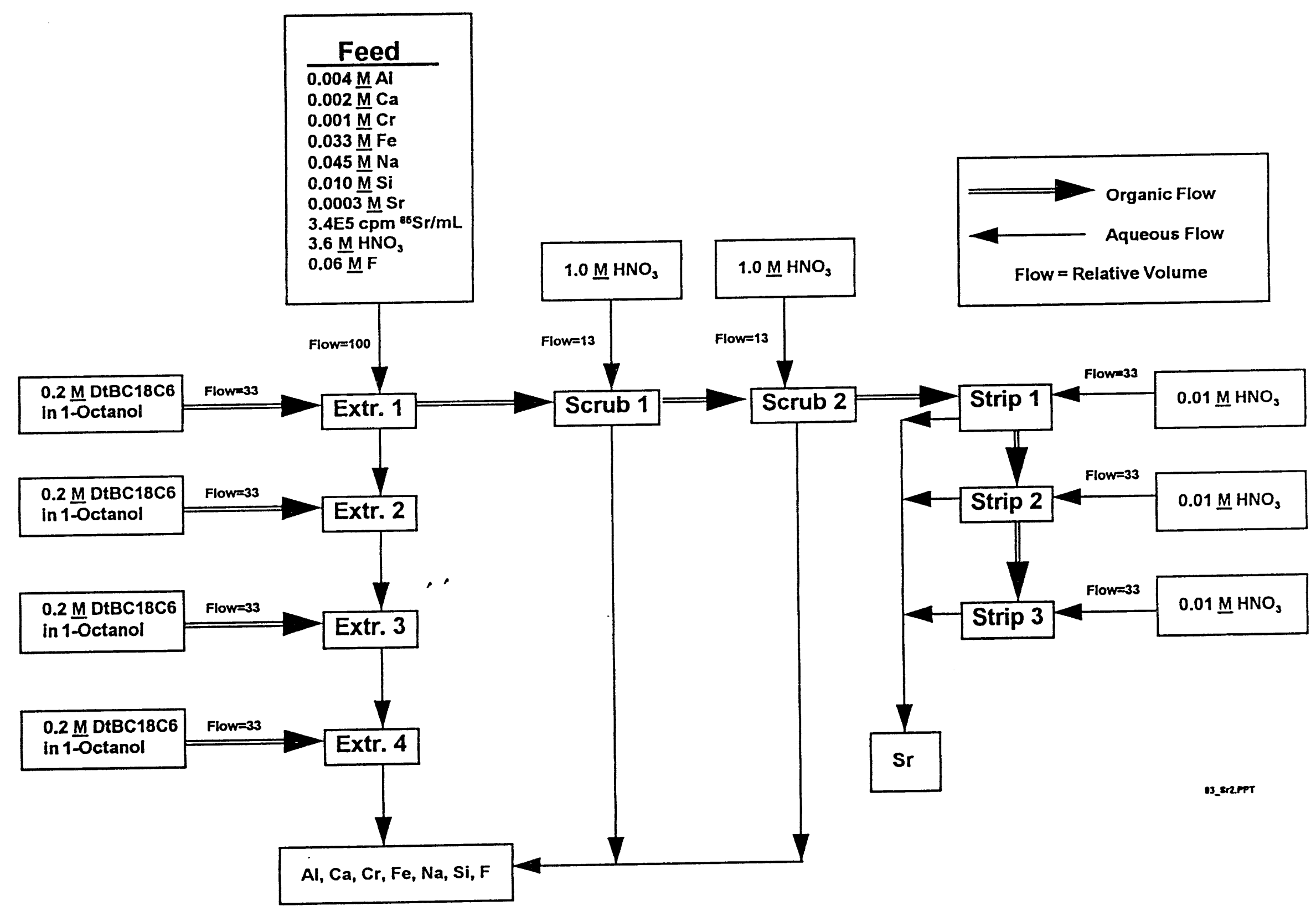


Remaining in Aqueous Phase, \%

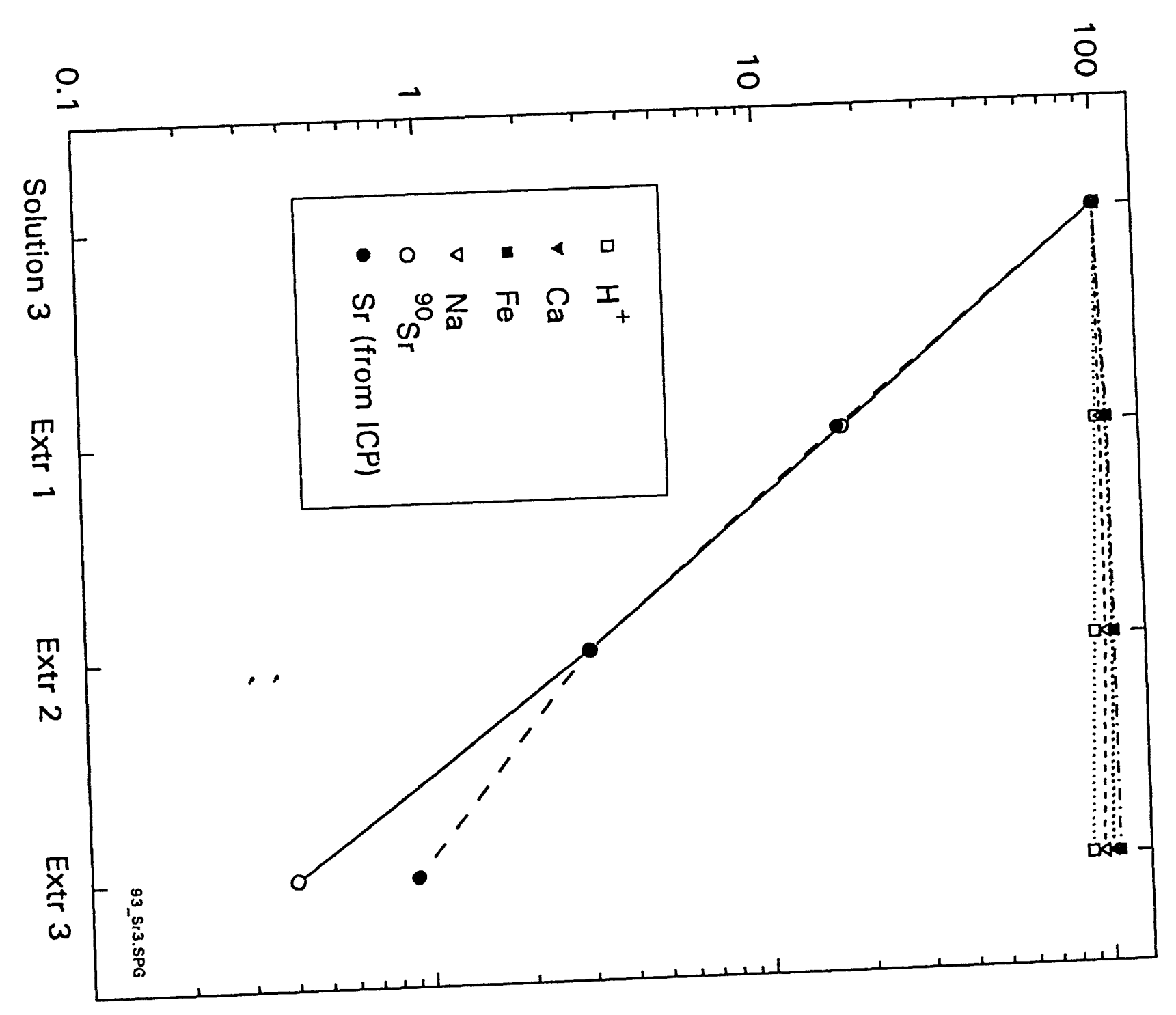




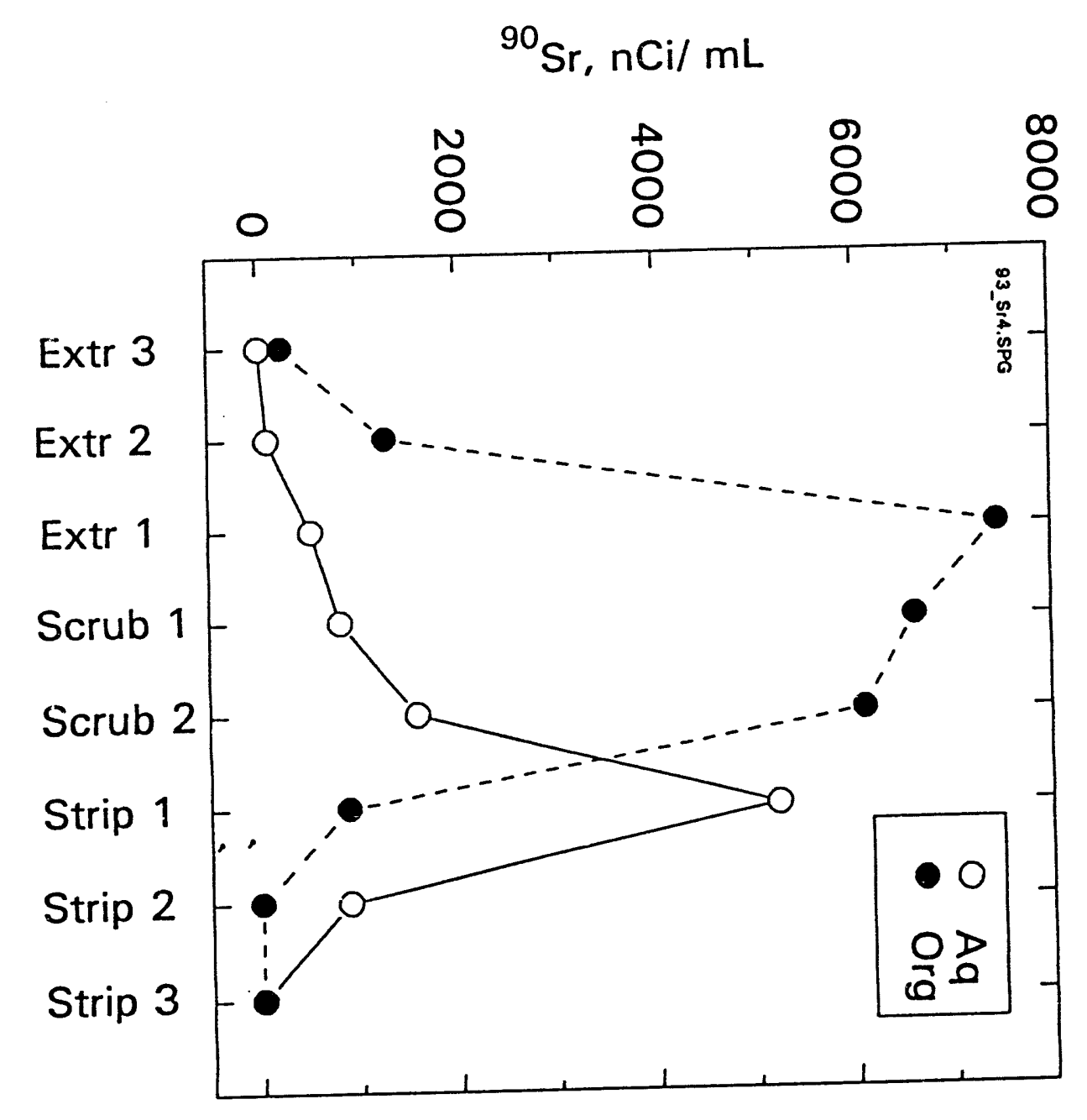




\section{Relative Sr Concentration}

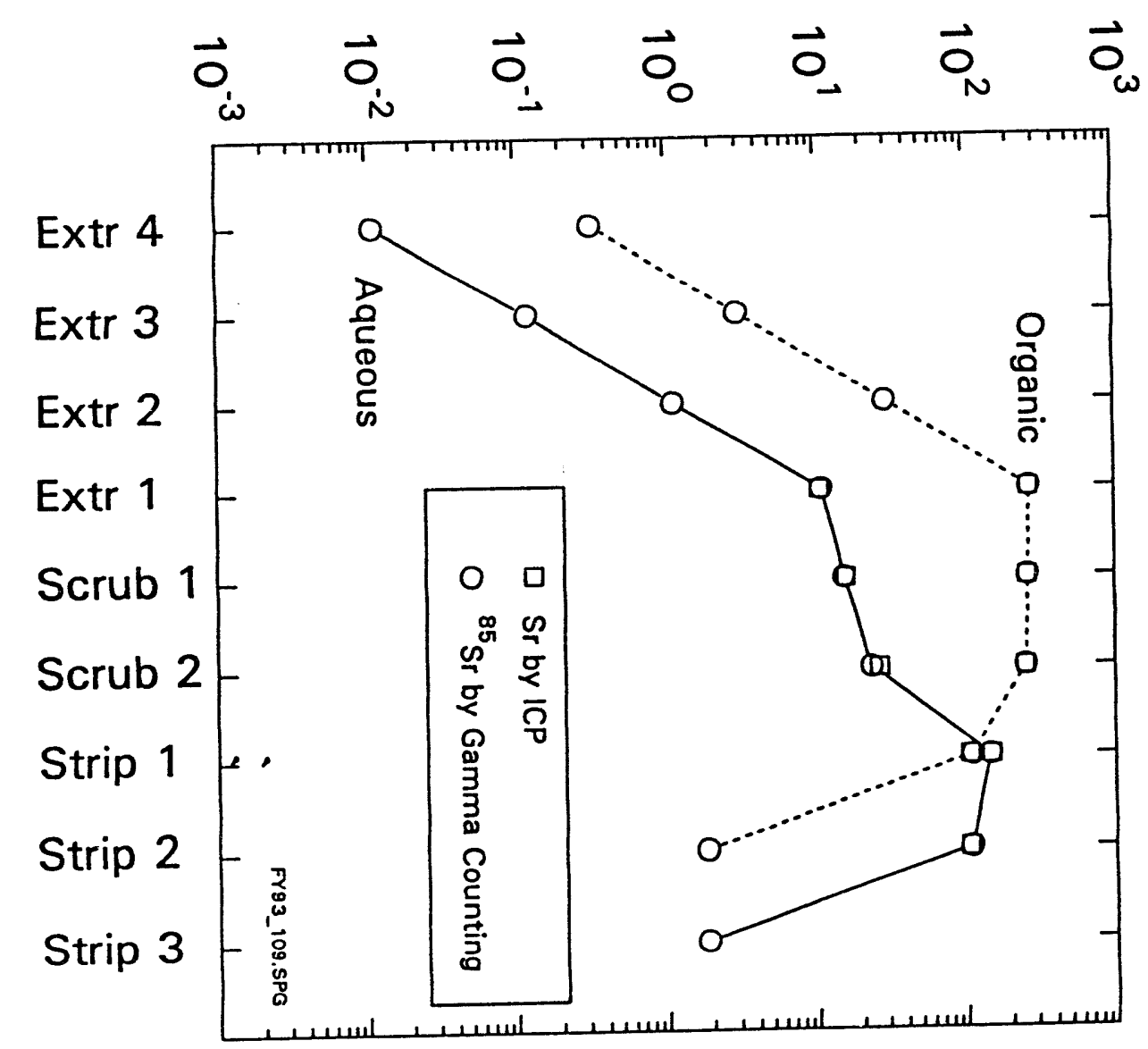




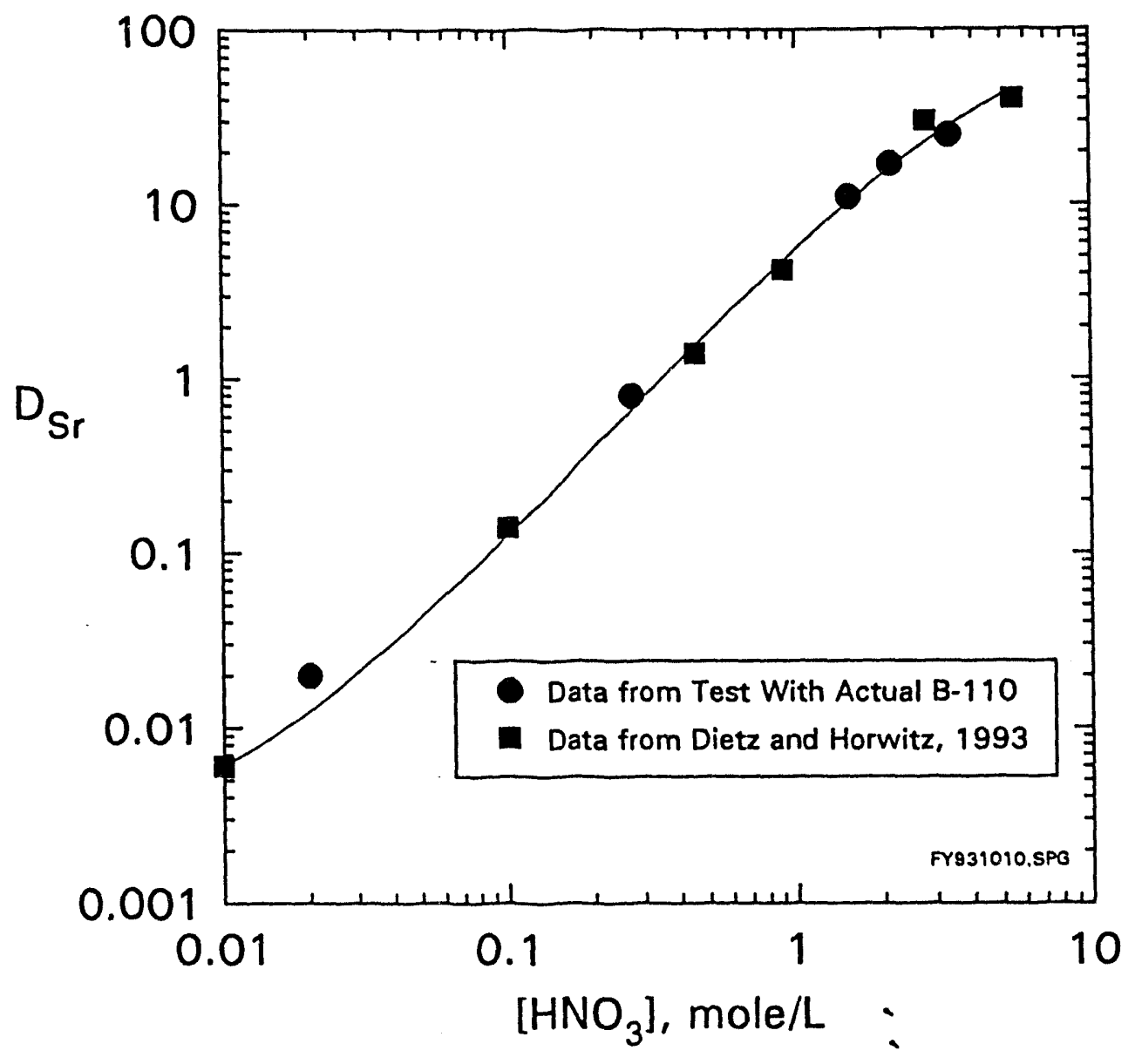



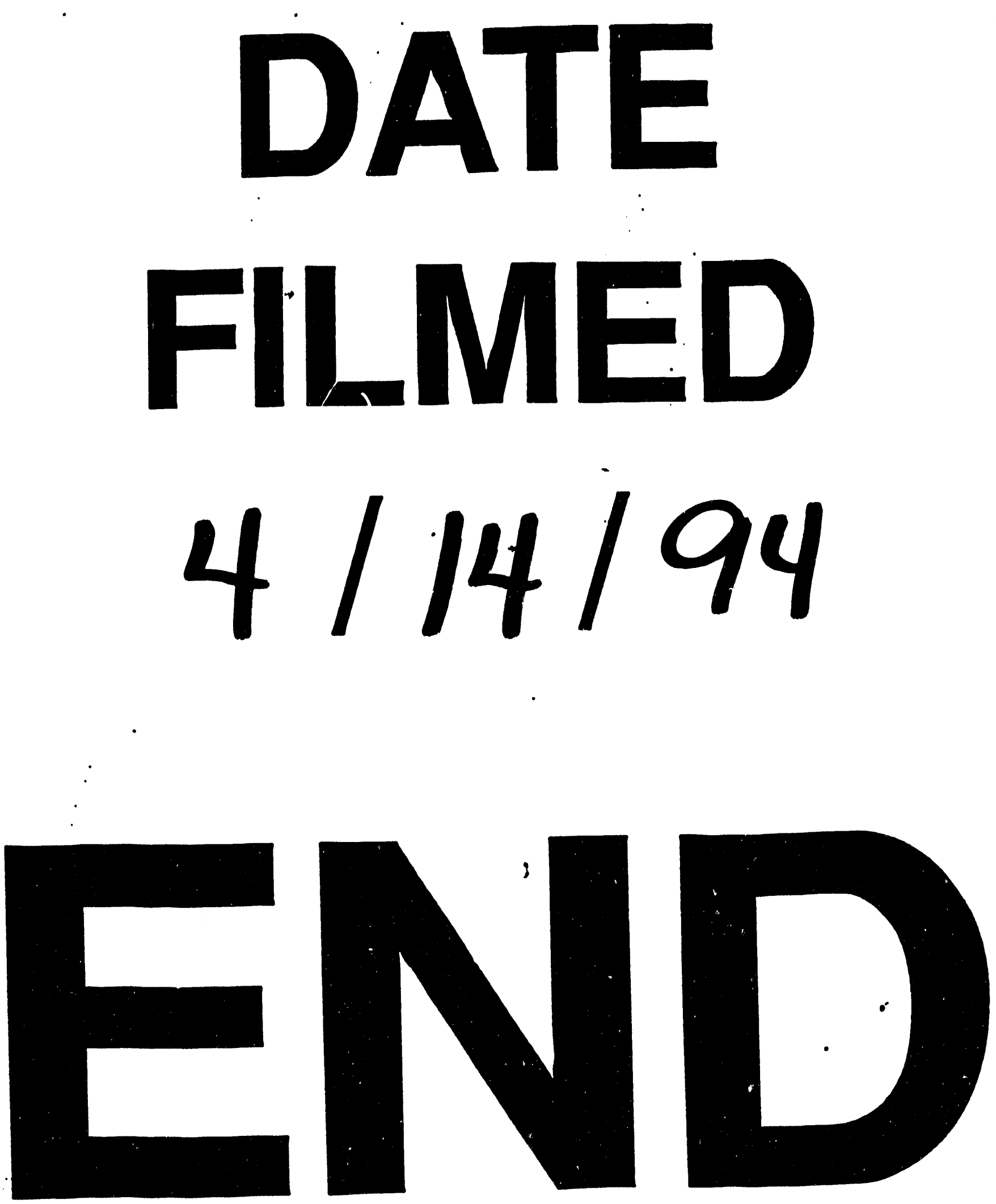


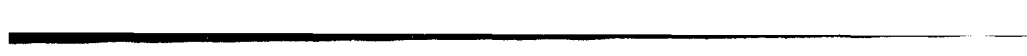

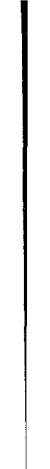

